\title{
HUBUNGAN ANTARA ANEMIA DENGAN PRESTASI BELAJAR PADA SISWI KELAS XI DI SMAN I ABIANSEMAL BADUNG
}

\author{
Ketut Ayu Hartarani Prasetya ${ }^{1}$, Desak Made Wihandani ${ }^{2}$, I Wayan Gede Sutadarma ${ }^{2}$ \\ ${ }^{1}$ Program Studi Pendidikan Dokter Fakultas Kedokteran Universitas Udayana \\ ${ }^{2}$ Departemen Biokimia Fakultas Kedokteran Universitas Udayana \\ ayuhartarani@gmail.com
}

\begin{abstract}
ABSTRAK
Anemia masih merupakan masalah kesehatan di Indonesia termasuk di Bali. Anemia defisiensi besi merupakan anemia defisiensi gizi yang paling lazim terjadi di negara-negara di dunia. Golongan yang rentan terhadap anemia adalah anak-anak, remaja putri, ibu hamil, pekerja rendahan dan penghuni lingkungan yang buruk. Defisiensi besi sebagai penyebab anemia terbanyak mengakibatkan kadar hemoglobin sebagai media transport oksigen dalam darah akan berkurang, sehingga bisa mengurangi laju metabolisme sel dan berpengaruh negatif terhadap perkembangan psikomotor serta intelektual seseorang sehingga terjadi penurunan produktivitas kerja maupun kemampuan konsentrasi belajar. Tujuan penelitian ini adalah untuk mengetahui hubungan antara anemia dengan pengaruhnya terhadap indeks prestasi belajar siswi kelas XI SMAN I Abiansemal. Penelitian ini merupakan observasional analitik dengan pendekatan cross sectional. Populasi dalam penelitian ini adalah siswi kelas XI SMAN I Abiansemal, berjumlah 213 orang. Kadar hemoglobin diperiksa dengan metode cyanmethHb dengan spectrophotometer. Berdasarkan hasil penelitian didapatkan bahwa jumlah siswi yang mengalami anemia berjumlah 10 orang $(4,7 \%)$ sedangkan yang tidak anemia berjumlah 203 orang $(95,3 \%)$. Prestasi belajar 213 siswi ada pada kategori baik $(66,2 \%)$ sedangkan sisanya pada kategori kurang $(33,8 \%)$. Siswi yang mengalami anemia dengan prestasi kurang sebanyak 6 orang $(5,3 \%)$ dan siswi dengan prestasi baik sebanyak 4 orang $(3,5 \%)$, sedangkan siswi yang tidak anemia dengan prestasi kurang sebanyak 66 orang $(30,9 \%)$ dan siswi dengan prestasi baik sebanyak 137 orang $(64,3 \%)$. Didapatkan hubungan prestasi belajar yang sangat lemah antara siswi yang anemia dengan yang tidak anemia, tetapi secara statistik tidak bermakna dengan $\mathrm{p}=0,091(\mathrm{p}>0,05)$.
\end{abstract}

Kata Kunci: Kadar Hemoglobin (Hb), Prestasi Belajar.

\begin{abstract}
Anemia is still a health problem in Indonesia, including in Bali. Iron deficiency anemia is a very common nutrition deficiency anemia that happens in the world. Groups who are vulnerable to these deficiencies are children, adolescent girls, pregnant women, a lowly worker and people who live in a bad environment. Iron deficiency as the major cause of anemia resulted in hemoglobin levels as media transport oxygen in the blood is reduced, which can reduce the rate of cell metabolism and negatively affect psychomotor and intellectual development of a person resulting in decreased work productivity and the abilities to concentrate in learning. The purpose of this study is to determine whether there is a relationship between anemia with learning achievement of grade XI students of SMAN 1 Abiansemal. This study is an observational and analytic study with cross sectional approach. The population for this study is the grade XI students of SMAN 1 Abiansemal, with total of 213 students. The hemoglobin level is checked with cyanmethHb method with spectrophotometer. Based on the results of the study showed that the number of girls who are anemic are 10 students $(4.7 \%)$, while the not anemic are 203 students (95.3\%). Learning achievement of 213 students in good category (66.2\%) while the rest are in the category of less (33.8\%). School girl with anemia with less achievement are 6 students (5.3\%) and female students with good achievement are 4 students (3.5\%), while the girls that are not anemic with less achievement are 66 students (30.9\%) and girls with good achievement are 137 people (64.3\%). In this study we obtained a very weak relationship of student learning achievement between anemic students with non anemic students but not statistically significant with $p=0.091$ ( $p>0.05)$.
\end{abstract}

Keywords: Hemoglobin level (Hb), learning achievement. 


\section{PENDAHULUAN}

Anemia merupakan kelainan hematologi yang sangat sering dijumpai baik di klinik maupun dimasyarakat. Anemia ialah keadaan dimana masa eritrosit dan/atau massa hemoglobin $(\mathrm{Hb})$ yang beredar tidak dapat memenuhi fungsinya untuk menyediakan oksigen bagi jaringan tubuh. Secara laboratorik dijabarkan sebagai kejadian penurunan di bawah normal kadar hemoglobin, hitung eritrosit dan hematokrit. ${ }^{1,3}$ Jenis anemia terbanyak adalah karena defisiensi zat besi.

Tanda-tanda anemia adalah 5L yaitu lemah, letih, lesu, lelah, dan lalai. Selain itu sering juga didapat keluhan seperti mata berkunang-kunang dan pusing, pucat pada mukosa kelopak mata, bibir, lidah, kulit, dan telapak tangan. ${ }^{2}$

Di dunia, ada 1,62 milyar orang yang terkena anemia, dimana golongan anak sekolah ada $33 \%$. Prevalensi anemia dunia menurut WHO masih berkisar 40-88\%. Berdasarkan Survei Kesehatan Rumah Tangga, prevalensi anemia anak usia sekolah dan remaja sekitar 26,5\%. Prevalensi anemia nasional menurut publikasi Riset Kesehatan Dasar (RISKESDAS) tahun 2008 adalah 11,3\% dimana anemia pada perempuan dewasa sebesar $11,9 \%$ dan anak-anak $12,8 \% .^{4}$

Berbagai faktor dapat mempengaruhi terjadinya anemia defisiensi besi antara lain pola makan, pola haid, pengetahuan mengenai resiko terjadinya anemia defisiensi besi, pengetahuan mengenai zat-zat yang dapat memicu terjadinya anemia karena zat tersebut dapat menghambat absorpsi besi (vitamin $\mathrm{C}$ dan teh), konsumsi obatobatan tertentu seperti antibiotik, aspirin, obat sulfonamide, obat malaria, merokok, pendarahan, luka bakar, diare, dan gangguan fungsi ginjal. ${ }^{3}$

Menurut Tarwoto, dkk penyebab anemia yang umum pada masyarakat di Indonesia (termasuk remaja putri) adalah lebih banyaknya konsumsi makanan nabati yang kandungan besinya kurang, dibandingkan dengan makanan hewani, sehingga kebutuhan tubuh akan zat besi tidak terpenuhi. Selain itu remaja putri juga biasanya ingin tampil langsing, sehingga membatasi asupan makanannya. ${ }^{15}$ Remaja putri lebih beresiko menderita anemia daripada remaja pria oleh karena setiap bulannya mengalami siklus haid (menstruasi), dimana dalam sekali siklus haid akan kehilangan $\pm 1,3 \mathrm{mg}$ zat besi per harinya, sehingga membuat kebutuhan zat besinya lebih banyak dari pada pria. ${ }^{6}$
Selain itu para remaja memiliki kesibukan yang relatif lebih tinggi baik dalam aktivitas belajar di sekolah maupun organisasi yang dapat mempengaruhi pola makan sehingga menjadi tidak teratur. Selain itu kebiasaan dalam mengonsumsi minuman yang dapat menghambat absorpsi zat besi sehingga nantinya akan mempengaruhi kadar hemoglobin seseorang. ${ }^{6}$

Dari studi juga menunjukkan, anak-anak dan remaja sangat rentan terhadap anemia defisiensi besi. Anak-anak dan remaja yang kurang mengkonsumsi zat besi, mendapat nilai yang lebih rendah pada tes intelegensi ${ }^{13}$. Perbedaan yang paling menonjol selama observasi antara siswa dengan anemia defisiensi besi dibandingkan dengan siswa yang sehat adalah dalam mengerjakan pekerjaan rumah, kemampuan sensoris, kemampuan fisik, perhatian dan konsentrasi, kemampuan belajar dan daya ingat. ${ }^{9}$

Berdasarkan latar belakang di atas seyogyanya perlu dilakukan evaluasi terhadap para siswi Sekolah Menengah Atas mengenai proporsi kejadian anemia dan hubungan antara anemia defisiensi besi dengan indeks prestasi belajar para siswi. Evaluasi dilaksanakan pada siswi-siswi kelas XI di SMAN 1 Abiansemal, Badung, Bali.

\section{BAHAN DAN METODE}

Penelitian ini merupakan penelitian deskriptif potong lintang, untuk melihat korelasi antara faktor resiko dengan efeknya, dimana subjek penelitian hanya di observasi sekali saja. Penelitian dilakukan pada siswi kelas I di SMAN 1 Abiansemal pada bulan Januari 2014. Pemeriksaan kadar hemoglobin $(\mathrm{Hb})$ darah menggunakan metode cyanmethHb menggunakan spectrophotometer. Dipakai acuan kadar kadar Hb kurang dari $10 \mathrm{~g} / \mathrm{dl}$ adalah anemia. Selanjutnya diperiksa prestasi akademiknya (Nilai Matematika dari buku raport semester I) pada bulan Maret 2014.

Sampel adalah seluruh siswi kelas XI SMAN I Abiansemal dan diperoleh jumlah sampel 213 orang. Ini sudah lebih dari besaran sampel minimal 140 orang untuk uji hubungan antara dua variabel.

Data dianalisis dengan analisis univariat dan bivariat menggunakan uji Fisher's Exact untuk melihat kemaknaan hubungan anemia dengan prestasi akademik siswi. 
HASIL

Karakteristik Subyek.

Penelitian dilakukan terhadap 213 siswi kelas XI SMAN I Abiansemal.

Tabel 1 : Jumlah Siswi yang diperiksa $\mathrm{Hb}$

\begin{tabular}{c|cc|c}
\hline No. & Kelas & Jumlah Siswi & Total Murid \\
\hline 1. & IPA 1 & 25 & 31 \\
2. & IPA 2 & 24 & 42 \\
3. & IPA 3 & 22 & 40 \\
4. & IPA 4 & 25 & 43 \\
5. & IPA 5 & 27 & 42 \\
6. & IPA 6 & 25 & 44 \\
7. & IPA 7 & 21 & 44 \\
8. & IPS 1 & 27 & 48 \\
9. & IPS 2 & 17 & 48
\end{tabular}

\begin{tabular}{lll} 
Total & 213 & 336 \\
\hline
\end{tabular}

Tabel 2 : Distribusi Anemia berdasarkan Kadar Hb.

\begin{tabular}{l|c|c}
\hline Variabel & $\begin{array}{c}\text { Jumlah } \\
\text { Siswi }\end{array}$ & $\begin{array}{c}\text { Persentase } \\
(\boldsymbol{\%})\end{array}$ \\
\hline Tidak & 203 & 95,3 \\
Anemia & 10 & 4,7 \\
\hline Total & 213 & 100 \\
\hline
\end{tabular}

Jumlah siswi yang mengalami anemia (kadar $\mathrm{Hb}<$ $10 \mathrm{~g} / \mathrm{dl})$ adalah 10 orang (4,7\%), yang tidak anemia 203 orang $(95,3 \%)$.
Tabel 3 : Distribusi Prestasi Belajar berdasarkan nilai mata pelajaran Matematika

\begin{tabular}{l|c|c}
\hline $\begin{array}{c}\text { Prestasi } \\
\text { Belajar }\end{array}$ & Jumlah Siswi & $\begin{array}{c}\text { Persentase } \\
(\boldsymbol{\%})\end{array}$ \\
\hline Baik & 141 & 66,2 \\
Kurang & 72 & 33,8 \\
\hline Total & 213 & 100 \\
\hline
\end{tabular}

Siswi dengan prestasi belajar kategori baik adalah 141 orang $(66,2 \%)$, dan kategori kurang 72 orang $(33,8 \%)$.

Tabel 4 : Hubungan antara Anemia dengan Prestasi Belajar siswi

\begin{tabular}{l|c|c|c|c|c}
\hline \multicolumn{1}{c}{ Siswi } & Prestasi Baik & Prestasi Kurang & Total & r & P \\
\hline Tidak Anemia & 137 & 66 & 203 & & \\
Anemia & $(64,32 \%)$ & $(33,98 \%)$ & $(95,3 \%)$ & 0,123 & 0,091 \\
& 4 & 6 & 10 & \\
\hline Total & $(1,88)$ & $(2,82 \%)$ & $(4,7 \%)$ & & \\
& 141 & 72 & 213 & \\
\end{tabular}

Jumlah 10 siswi yang mengalami anemia $(\mathrm{Hb} \leq 10$ g\%) dengan prestasi akademik kurang sebanyak 6 orang $(2,82 \%)$ dan prestasi baik 4 orang $(1,88 \%)$, sedangkan 203 siswi yang tidak anemia $(\mathrm{Hb}>10$ g\%), sebanyak 66 orang $(30,98 \%)$ mempunyai prestasi akademik kurang, dan 137 orang $(64,32 \%)$ dalam katagori prestasi akademik baik.

Dengan analisis bivariat Fisher's Exact antara variabel kejadian anemia dengan prestasi belajar diperoleh korelasi $\mathrm{r}=0,123$ dan $\mathrm{p}=0,091$ ( $p>0,05)$ maka didapatkan hubungan yang sangat lemah antara anemia dengan prestasi belajar siswi namun secara statistik tidak bermakna.

\section{PEMBAHASAN}

Penelitian yang dilakukan di SMAN 1 Abiansemal terhadap 213 siswi yang menjadi sampel dan diperiksa kadar Hemoglobin darahnya diperoleh hasil bahwa 10 siswi $(4,7 \%)$ mengalami anemia dan 203 orang $(95,3 \%)$ tidak anemia, dengan batasan dianggap anemia bila kadar Hemoglobin darah $\leq 10$ $\mathrm{g} / \mathrm{dl} .^{3}$

Prestasi belajar merupakan evaluasi hasil belajar siswi atau nilai matematika dalam rapor kelas XI SMAN 1 Abiansemal. Hasil pengamatan menunjukkan siswi responden yang memiliki prestasi 
belajar yang baik berjumlah 141 orang $(66,2 \%)$ sedangkan yang memiliki prestasi kurang 72 orang $(33,8 \%)$. Jumlah siswi anemia tapi mempunyai prestasi baik sebanyak 4 orang $(1,88 \%)$, dan yang mempunyai prestasi kurang sebanyak 6 orang $(2,82 \%)$. Siswi yang tidak anemia dengan prestasi baik adalah sebanyak 137 orang $(64,32 \%)$, dan yang dengan prestasi kurang sebanyak 66 orang $(30,98 \%)$. Dari hasil penelitian ini didapatkan hubungan yang sangat lemah antara anemia dengan prestasi belajar siswi kelas XI SMAN 1 Abiansemal, Badung, Bali, namun secara statistik tidak bermakna dimana $\mathrm{p}=$ $0,091(\mathrm{p}>0,05)$.

Hasil yang diperoleh ini menunjukkan keadaan yang baik, bahwa kejadian anemia pada siswi remaja kelas XI SMAN Abiansemal lebih rendah daripada rata-rata persentase kejadian anemia di masyarakat Indonesia. Ini mungkin disebabkan oleh pengetahuan mengenai kecukupan gizi siswi sudah cukup dimengerti disamping keadaan sosial ekonomi masyarakat yang semakin membaik dan bisa mencukupi kebutuhan primer makanan bagi keluarga. Masih tetap dibutuhkan observasi yang berkelanjutan dimasa mendatang agar kejadian anemia di masyarakat dapat terus ditekan sekecil mungkin mengingat banyak faktor yang dapat mempengaruhi kecukupan gizi masyarakat kita.

Sebagai perbandingan adalah penelitian terdahulu yang dilakukan oleh Saadah dan Santoso di SMP Negeri 2 Magetan, diperoleh hasil hubungan yang signifikan antara kadar hemoglobin darah dan hasil belajar siswa. ${ }^{13}$

Tetapi hasil ini berbanding terbalik dengan penelitian yang dilakukan oleh Alfiyanah di SMA Negeri 14 Semarang dimana terdapat hubungan yang bermakna antara kadar hemoglobin darah dengan hasil belajar siswa. ${ }^{1}$

Hasil penelitian yang dilakukan oleh Gita Amalia, dkk untuk mengetahui hubungan kadar Hemoglobin dengan prestasi belajar yang dilakukan pada mahasiswa PS D3 Kebidanan STIKES Widya Husada Semarang memperoleh hasil bahwa tidak ada hubungan $(\mathrm{p}=1,00)$ antara keduanya. ${ }^{5}$

Penelitian yang juga dilakukan oleh Maarial pada siswi SMPN 11 Manado menunjukkan hasil yang sama yaitu tidak terdapat hubungan antara kejadian anemia dengan hasil belajar. ${ }^{8}$

\section{SIMPULAN}

Dari penelitian ini dapat disimpulkan bahwa hubungan kadar Hemoglobin dengan prestasi akademik dari 213 siswi SMAN 1 Abiansemal, Badung adalah sangat lemah dan secara statistik tidak bermakna.

\section{DAFTAR PUSTAKA}

1. Alfiyanah, S. Hubungan Antara Kadar Hemoglobin Darah Dan Status Iodium Dengan Prestasi Belajar Siswi SMA Negeri 14 Semarang.2010
2. Anie Kurniawan.. Gizi seimbang untuk mencegah anemia. 1998

3. Bakta, I Made.. Hematologi Klinis Ringkasan. EGC, Jakarta.2007

4. Departemen Kesehatan RI. RISKESDAS. Jakarta, Depkes RI. 2008.

5. Gita Amallia Nur Istiqomah, Rinayati, Chusnul Zulaika, Didik Wahyudi; hubungan kadar Hemoglobin dengan prestasi belajar yang dilakukan pada mahasiswa PS D3 Kebidanan STIKES Widya Husada Semarang, 2012. Prosiding SNST ke-4 FT Universitas Wahid Hasyim Semarang 2013.

6. Hanafiah, M.J., 2009. Haid dan Siklusnya. In: Wiknjosastro, H. ed. Ilmu Kandungan Edisi Kedua Cetakan Ketujuh. Jakarta: PT. Bina Pustaka Sarwono Prawihardjo,2009.h. 103-104.

7. Kamus Kedokteran Dorland. 2007. 31st. Ed. Jakarta : EGC.

8. Maarial. N. 2011. Hubungan antara kejadian anemia dengan hasil belajar siswi SMPN 11 Manado, http://idimanado.org/wpcontent/uploads/2012/07/Hubungan-AntaraKejadian-Anemia-Dengan-Hasil-BelajarSiswi.pdf.

9. Nachvak, M., Rezaei, M.. The Relationship Iron Deficiency And Academic Performance Among Mental Low Ability Students. Journal of Exceptional Children. Vol 1.2006

10. Notoadmodjo, Prof. Dr. Soekidjo. Metodologi Penelitian Kesehatan, Edisi Revisi. Jakarta: Rineka Cipta.2005

11. Oktaviana. 2012. Jurnal. Hubungan Kejadian Gizi Kurang, Anemia Gizi Besi Dan GAKY Dengan Prestasi Belajar. Unnes Journal Of Public Health, ISSN: Universitas Negeri Semarang.2012;1(2):2252-6781

12. Pollitt, E. 1993. Iron Deficiency And Cognitive Function Annual Review of Nutrition, 1993; 13: 521-537.

13. Saadah, N; Santoso, B.J. 2010. Hubungan Kadar Hemoglobin Dengan Prestasi Belajar Siswa Kelas VII Di SMP Negeri 2 Magetan. 
14. Soleimani, N., Abbaszadeh, N. Relationship Betwee Anaemia, Caused From The Iron Deficiency, And Academic Achievement Among Third Grade High School Female Students. Social and Behavioral Science 29 (2011) 1887 1884

15. Tarwoto, Ns. Dkk. . Kesehatan Remaja problem dan olusinya.Jakarta: Salemba Medika.2010 
